\title{
Degree of phytate conversion and type of phytase A modify production parameters and egg shell quality in laying hens*
}

\author{
K. $\dot{Z} y l a{ }^{1}$, M. Mika ${ }^{1}$, J. Koreleski ${ }^{2}$ and S. Świątkiewicz ${ }^{2}$ \\ ${ }^{1}$ Agricultural University of Cracow, \\ Department of Food Biotechnology \\ Al. 29-Listopada 46,31-425 Kraków, Poland \\ ${ }^{2}$ National Research Institute of Animal Production, \\ Department of Animal Nutrition and Feed Science \\ 32-083 Balice, Poland
}

\begin{abstract}
At low levels of dietary calcium and phosphorus (2.8 and $0.36 \%$, respectively), the degree of phytate conversion raised by adding phytase B to feeds that had already been supplemented with 3- or 6-phytase A, modulated production parameters, and egg shell quality of Hy Line Brown laying hens fed maize-soyabean meal from week 40 to 54. Feed consumption, laying rate, mean egg weight and shell breaking strength depended on the type of phytase A added to feeds only at a low phytate conversion degree. Egg production and feed per egg conversion ratio did not depend on the dietary supplements studied.
\end{abstract}

KEY WORDS: laying hens, phytase, phytate, conversion degree

\section{INTRODUCTION}

The theory of enzymic breakdown of phytate compounds distinguishes between liberation of phytate molecules from complexes with other tissue components and enzymic cleavage of phosphate residues on the myo-inositol ring. The extent of dephosphorylation may be expressed by the dephosphorylation level, defined as the percentage of total phosphorus that is removed from feeds. The extent of phytate conversion, on the other hand, may be expressed by a conversion degree

\footnotetext{
* Supported by the State Committee for Scientific Research, Grant No. 6 P06E 05220

${ }^{1}$ Corresponding author: e-mail: kzyla@ar.krakow.pl
} 
(CD), that is a percentage of total myo-inositol freed from feeds. The conversion degree may be effectively stimulated by phytase B (Żyła et al., 2004), whereas the dephosphorylation level is altered by phytases A, organic acids or both. Phytate molecule should be perceived not only as a chelating agent, whose antinutritional properties can be reduced by phytase A, but also as a source of myo-inositol and lower phosphates of myo-inositol supplied by the joint action of phytases A and B.

The objectives of the current study were to determine the efficacy of commercial 3- and 6-phytases A at different conversion degrees in laying hens fed calcium- and phosphorus-deficient maize-soyabean meal diets.

\section{MATERIAL AND METHODS}

Fifty-four Hy Line Brown laying hens were placed in wired cages and divided into 6 dietary treatments with 3 cage replicates of 3 hens each. Experimental diets and water were provided ad libitum from week 40 to 54 . The basal $\mathrm{Ca}$ and $\mathrm{P}$ deficient diet $(2.8 \% \mathrm{Ca}$ and $0.36 \%$ total $\mathrm{P})$ was composed of $(\mathrm{g} / \mathrm{kg})$ : maize, 681 ; soyabean meal, 240; limestone, $70 ; \mathrm{NaCl}, 3$; vitamin and mineral premix, 5; and DL-methionine, 1. It was supplemented with phytase B at $50000 \mathrm{PHFU} / \mathrm{kg}$ and two commercial phytases A (3- or 6- phytase A) at $250 \mathrm{FTU} / \mathrm{kg}$ or unsupplemented. The experimental design was $3 \times 2$ factorial with 3 levels of phytase A (none, 3-phytase, 6-phytase) and two levels (low, high) of phytate conversion degree. Feed consumption, feed per egg, egg production, mean egg weight, laying rate, and shell breaking strength were measured. Data were analysed by Statgraphics Plus for Windows v.5.1 statistical software. Mean differences were determined using Fisher's LSD test. Statistical significance was accepted at $\mathrm{P}<0.1$.

\section{RESULTS}

Significant treatment effects were observed for feed consumption $(\mathrm{P}<0.01)$, egg weight $(\mathrm{P}<0.1)$, laying rate $(\mathrm{P}<0.05)$ and shell breaking strength $(\mathrm{P}<0.01)$, but egg production and feed per egg conversion ratio did not depend on dietary supplements (Table 1). Feed consumption was affected by the phytase addition $(\mathrm{P}<0.05)$ and there was a significant interaction between phytase and $\mathrm{CD}(\mathrm{P}<0.01)$. To the contrary, egg weights depended on $\mathrm{CD}(\mathrm{P}<0.1)$ and not on phytase level, but again, the interaction between experimental factors was significant $(\mathrm{P}<0.05)$. Dietary supplements did not affect laying rate directly, but their effect was expressed in the significance of the phytase $\times \mathrm{CD}$ interaction. Both phytase level and CD significantly altered shell breaking strength $(\mathrm{P}<0.05$ and 0.01 , respectively). 
Table 1. Influence of phytate conversion degree (CD: L- no addition, H- phytase B), and phytase (none, or 3- or 6-phytase A) on feed consumption (FC), feed per egg (FE), egg production (EP), egg weight (EW), laying rate (LR), and shell breaking strength (SBS) ${ }^{1}$

\begin{tabular}{|c|c|c|c|c|c|c|c|}
\hline \multirow{2}{*}{$\mathrm{CD}$} & \multirow{2}{*}{ Phytase A } & $\mathrm{FC}$ & $\mathrm{FE}$ & EP & EW & LR & SBS \\
\hline & & g-hen-day & $\mathrm{g}$ & $\mathrm{kg}$ & $\mathrm{g}$ & $\%$ & $\mathrm{~N}$ \\
\hline $\mathrm{L}$ & 0 & $117^{\mathrm{c}}$ & 126 & 16.67 & $62.1^{\mathrm{a}}$ & $93.1^{\mathrm{c}}$ & $35.5^{\mathrm{a}}$ \\
\hline $\mathrm{L}$ & $3 \mathrm{~A}$ & $117^{\mathrm{c}}$ & 133 & 16.12 & $65.5^{\mathrm{cd}}$ & $91.5^{\mathrm{bc}}$ & $36.2^{\mathrm{a}}$ \\
\hline $\mathrm{L}$ & $6 \mathrm{~A}$ & $107^{\mathrm{a}}$ & 128 & 14.76 & $62.6^{\mathrm{ab}}$ & $80.8^{\mathrm{a}}$ & $40.0^{\mathrm{b}}$ \\
\hline $\mathrm{H}$ & 0 & $116^{\mathrm{bc}}$ & 136 & 15.81 & $66.7^{d}$ & $85.0^{\mathrm{ab}}$ & $37.0^{\mathrm{ab}}$ \\
\hline $\mathrm{H}$ & $3 \mathrm{~A}$ & $112^{\mathrm{ab}}$ & 127 & 15.58 & $63.4^{\mathrm{ad}}$ & $88.3^{\mathrm{ac}}$ & $40.7^{\mathrm{b}}$ \\
\hline $\mathrm{H}$ & $6 \mathrm{~A}$ & $116^{\mathrm{bc}}$ & 130 & 16.36 & $65.9^{\mathrm{cd}}$ & $89.0^{\mathrm{bc}}$ & $40.9^{b}$ \\
\hline \multicolumn{2}{|c|}{ SEM } & 1.48 & 5.02 & 0.62 & 1.10 & 2.51 & 1.17 \\
\hline \multicolumn{8}{|c|}{ Probability } \\
\hline \multicolumn{2}{|c|}{ treatment effect } & 0.001 & NS & NS & 0.055 & 0.046 & 0.008 \\
\hline \multicolumn{2}{|c|}{$\mathrm{CD}$} & NS & NS & NS & 0.054 & NS & 0.002 \\
\hline \multicolumn{2}{|c|}{ phytase A } & 0.024 & NS & NS & NS & NS & 0.050 \\
\hline \multicolumn{2}{|c|}{$\mathrm{CD} \times$ phytase $\mathrm{A}$} & 0.002 & NS & NS & 0.023 & 0.019 & NS \\
\hline
\end{tabular}

${ }^{1} 3$ - and 6-phytase A added at $250 \mathrm{FTU} / \mathrm{kg}$, High CD produced by phytase B supplementation at $50000 \mathrm{PHFU} / \mathrm{kg}$

${ }^{a b c}$ means within columns with different superscripts differed significantly at $\mathrm{P} \leq 0.05$

\section{DISCUSSION}

In the experiment, laying hens were fed low $\mathrm{P}$, low Ca diets, so that the influence of phytases $\mathrm{A}$ and $\mathrm{CD}$ on calcium metabolism is assessed. The most sensitive and commonly used indicators of Ca metabolism in laying hens are those related to eggshell quality (Gordon and Roland, 1998). The quality of eggshells measured as shell breaking strength was enhanced by both phytases A and a significant impact of the CD level was also recorded. In fact, at low CD, only 6-phytase A improved shell breaking strength significantly, providing indirect evidence that myo-inositol phosphate intermediates produced by the enzyme modulate calcium metabolism by a highly specific mechanism that prevents the metabolites of 3-phytase A from playing a similar role.

For feed consumption, the nature of the interaction between phytase and CD demonstrated that 6-phytase A reduced feed consumption only at low $\mathrm{CD}$ and also that the increase in CD improved the efficacy of 6-phytase A and reduced the effectiveness of 3-phytase A. These findings confirm observations made previously by many authors who observed the positive effect of 3-phytase A on feed consumption in laying hens. All of those observations were performed exclusively at a low CD level. To our knowledge, there are no literature data on the efficacy of 6-phytase A and phytase B in laying hens. 
The mean egg weight was enhanced by rising $\mathrm{CD}$, and, again, the effectiveness of 6-phytase A was high only at the high CD level. For laying rate, significant interaction between dietary factors was expressed in low values of the parameter only in hens fed the diet supplemented with 6-phytase A at low CD. All the observations agree with our previous findings (Żyła et al., 2004) that show that myo-inositol phosphates released through simultaneous action of 3-phytase A and phytase B affect bird physiology differently than intermediates accumulated by the action of 6-phytase A and phytase B.

The lack of response to dietary supplements observed for feed per egg conversion ratio as well as for egg production is consistent with findings provided by other researchers (Boling et al., 2000).

\section{CONCLUSIONS}

In laying hens fed phosphorus- and calcium-deficient diets, production parameters and egg shell quality are modulated by 6-phytase A differently than by 3-phytase A. Raising the phytate conversion degree by the addition of phytase B to feeds that had already been supplemented with a phytase A additionally affects hen performance.

\section{REFERENCES}

Boling S.D., Douglas M.W., Johnson M.L., Wang X., Parsons C.M., Koelkebeck K.W., Zimmerman R.A., 2000. The effects of dietary available phosphorus levels and phytase on performance of young and older laying hens. Poultry Sci. 79, 224-230

Gordon R.W., Roland D.A., 1998. Influence of supplemental phytase on calcium and phosphorus utilization in laying hens. Poultry Sci. 77, 290-294

Żyła K., Wikiera A., Mika M., Stodolak B., Koreleski J., Świątkiewicz S., 2004. Towards complete dephosphorylation and total conversion of phytates in poultry feeds. Poultry Sci. 83, 11751186

\section{STRESZCZENIE}

Wpływ fitaz A oraz stopnia konwersji fitynianów na wskaźniki produkcyjne i wytrzymałość skorupy jaj u kur niosek

W mieszankach kukurydziano-sojowych o niskiej zawartości fosforu i wapnia (0,36\% P ogólnego i 2,8\% Ca) stopień konwersji fitynianów, z dodatkiem fitazy B do pasz zawierających 3- lub 6fitazę A, wpływał na wskaźniki produkcyjne i jakość skorupy jaj u niosek. Zużycie paszy, nieśność, średnia masa jaja oraz wytrzymałość skorupy jaja zależały od rodzaju fitazy A dodanej do paszy tylko przy niskim stopniu konwersji fitynianów. Produkcyjność niosek Hy Line Brown oraz współczynnik wykorzystania paszy (w przeliczeniu na jajko) nie zależały od poziomu dodanych fitaz. 